\title{
FACTORS AFFECTING ANXIETY OF MOTHERS WITH LOW-BIRTH-WEIGHT BABIES IN SOUTHWEST SUMBA DISTRICT, EAST NUSA TENGGARA PROVINCE
}

\author{
Conchita Emiliana Ndapa ${ }^{1}$ \\ Correspondence: conchitaemily@student.ub.ac.id \\ ${ }^{1}$ Dinas Kesehatan Kabupaten Sumba Barat Daya Provinsi Nusa Tenggara Timur, Indonesia
}

\section{ABSTRACT}

The World Health Organization (WHO) states that $60-80 \%$ of the infant mortality rate (IMR) occurs due to low birth weight. Low Birth Weight (LBW) contributes 60\% -80\% of neonatal mortality. The Indonesian Health Demographic Survey (IDHS) in 2017 showed that the incidence of LBW in Indonesia reached $6.2 \%$ with a fairly high prevalence. These various effects of LBW are what then causes babies to often require intensive care in the hospital. This condition can then lead to anxiety in parents. Therefore, this study was conducted to determine the factors that influence anxiety in mothers who have babies with LBW conditions in Southwest Sumba Regency. This research was conducted on 20-26 March 2021 with a qualitative approach through interviews and measuring anxiety levels using the HARS questionnaire. The study population was all mothers who had LBW babies in Southwest Sumba. The research subjects were 6 respondents who were selected through the purposive sampling technique. The results showed that there were several factors that influenced the anxiety of mothers with LBW babies, including the mother's age at pregnancy, the amount of parity, and education.

Keywords: anxiety, low-birth-weight, parity, pregnancy.

\section{Article History:}

Received: April 5, 2021

Accepted: June 12, 2021

Published: September 30, 2021
Cite this as: Ndapa, C.E. Factors affecting anxiety of mothers with low-birth-weight babies in southwest sumba district, East Nusa Tenggara Province..Journal of Psychiatry Psychology and Behavioral Research; 2021. Vol. 2, Issue 2. p:7-10.

\section{INTRODUCTION}

LBW is one of the causes of infant mortality (IMR) with a relatively high incidence rate in Indonesia. IMR is the number of babies who died before reaching the age of 1 year which is expressed in 1,000 live births in the same year. The World Health Organization (WHO) states that $60-80 \%$ of the infant mortality rate (IMR) occurs due to low birth weight. LBW is defined as a condition in which a baby is born weighing less than 2500 grams. Low Birth Weight (LBW) contributes 60\% $80 \%$ to neonatal mortality with a prevalence of LBW incidence of 20 million (15.5\%) annually in the world and developing countries being the largest contributor, reaching $96.5 \%$. Meanwhile, according to the Indonesian Health Demographic Survey (IDHS) in 2017, the incidence of LBW in Indonesia reached $6.2 \%$ with a high prevalence. In addition, Indonesia is ranked 9th highest in the world in terms of the incidence of LBW, which is more than $15.5 \%$ of baby births every year. ${ }^{1}$

About a third of LBW died before stabilization or within the first 12 hours of a baby's life. ${ }^{2}$ This is what causes LBW as one of the most common causes of neonatal mortality. According to the results of research conducted by Gogoi, (2018) in India, it shows that the type of delivery method, the place of residence, the mother's educational status, the mother's occupation, religion, and monthly income are sociodemographic factors that affect the weight of the baby at birth. In addition, mothers who experience pregnancy at a risky age are also a risk factor for LBW. ${ }^{3}$ In terms of age, a good age to get pregnant is the productive age, namely $21-35$ years. The status of parents who are active smokers also has a significant effect on low baby weight after birth. ${ }^{4}$

The high mortality rate for LBW infants in developing countries such as Asia and Africa is caused by inadequate facilities for the care of premature babies or $\mathrm{LBW}^{5}$ Meanwhile, the exact cause of the birth of a baby with low birth weight is not yet known. It is suspected that the cause of LBW in developing countries such as Asia and Africa is nutrition during pregnancy, while the cause in developed countries is thought to come from the age factor of mothers who give birth over the age of 35 years. In addition, the incidence of LBW caused by premature babies with lung conditions that are not yet fully matured puts LBW at risk of 
asphyxia. LBW incidence is one of the causes of death in the first month of birth of a baby. LBW can cause a variety of quite serious impacts during the process of growth and development in newborns. Cognitive development disorders such as mental retardation are at greater risk in infants with LBW conditions. In addition to increasing the morbidity and mortality rates for infants, LBW conditions also result in a poor immune system compared to babies with normal weight so that they are more prone to infections which can lead to illness or even death. ${ }^{6}$ LBW is also a major determinant of stunting in infants aged 12-24 months in Indonesia. ${ }^{7}$

These various effects of LBW are what then causes babies to often require intensive care in the hospital (hospitalization) until the baby's condition is stable and then ready to be treated at home. The care for LBW babies who are in the Neonatal Intensive Care Unit (NICU) or the Perinatology room with various equipment such as invasive breathing aids, infusions, NGT, care in an incubator, and heating lamps cause the baby to be separated from the reach of its parents. This condition can then lead to anxiety in parents due to limited opportunities to interact with babies. ${ }^{8}$

Anxiety as a psychosocial health problem often occurs in pregnant and postpartum women, besides the risk of stress and depression. Anxiety is an unclear and pervasive worry associated with feelings of uncertainty and helplessness. The mother's guilt and other emotions such as sadness, frustration, anger, and anxiety about the baby's condition can worsen over time. The level of anxiety itself consists of several levels such as mild anxiety, moderate anxiety, and severe anxiety. Based on the results of research conducted by Humaira and Rifdi, (2019) mentioned that the mother's anxiety is in the form of a change in understanding of the baby's health status and the actions taken by the baby while being treated in the Intensive room. Similar research by Mutiara and Hastuti (2016) states that it shows that the majority of the parents of LBW babies are young adults $(76.6 \%)$, have low education $(80 \%)$, and moderate-severe anxiety levels $(70 \%)$. Where there are various kinds of driving factors for anxiety in mothers with LBW babies. Therefore, to determine these factors, a study was conducted on the factors that influence anxiety in mothers who have babies with LBW conditions in Southwest Sumba Regency.

\section{METHOD}

In this study, the authors used a qualitative approach, namely through interviews. The type of research used in this research is descriptive research type. which aims to explain the various factors of anxiety that are at risk experienced by mothers who give birth to babies with LBW conditions in Southwest Sumba Regency. This research was conducted on March 20-26, 2021 which took place in Southwest Sumba Regency. The population in this study were all mothers who had LBW babies in Southwest Sumba. Meanwhile, the research sample of mothers who had LBW babies in 2020 was as many as 6 people. In this research, The selection of informants is carried out using the purposive sampling technique, which is based on the criteria of the researcher who is considered to be by their role so that accurate information can be obtained. The selected informants were the informant group of mothers who had LBW babies. The research instrument is the researcher himself using in-depth interviews, a scale for measuring anxiety using the Hamilton Rating Scale for Anxiety (HARS), observation sheets, and recording tools. This interview guide contains a list of questions to be asked to informants according to the HARS questionnaire. as well as recording tools. This interview guide contains a list of questions to be asked to informants according to the HARS questionnaire. as well as recording tools. This interview guide contains a list of questions to be asked to informants according to the HARS questionnaire.

\section{RESULT}

Majority of mothers who were research subjects were at the ideal age during pregnancy with a percentage of $83 \%$ or as many as 5 respondents. Some mothers had a history of primiparous (50\% or 3 respondents) and multiparous (50\% or 3 respondents). Most of the mother's education history is at the junior high school level, with as many as 3 responses. Meanwhile, the level of anxiety experienced by the majority of mothers was in the form of mild anxiety, namely 5 respondents and 1 respondent did not have anxiety. The results of the interview showed that on average the mothers answered that they did not know the characteristics of babies with LBW so they felt anxious about the next treatment that would be given to these LBW babies. In addition to mothers with low birth weight babies, Husband and family support is needed to support and assist mothers in taking care of LBW babies because 2 out of 6 mothers give birth to twins in LBW conditions. Maternal anxiety will also be reduced after receiving education from health workers and receiving regular home visits from village midwives, followed by continuous monitoring of the baby's development (Table 1).

Table 1. Characteristics of Subjects

\begin{tabular}{|c|c|c|}
\hline Characteristics & $\mathrm{N}$ & $\%$ \\
\hline $\begin{aligned} \text { Age } & \\
& <20 \text { years } \\
& \geq 20-35 \text { years }\end{aligned}$ & $\begin{array}{l}1 \\
5\end{array}$ & $\begin{array}{l}17 \\
83\end{array}$ \\
\hline $\begin{array}{l}\text { Parity } \\
\quad \text { Primipara } \\
\quad \text { Multiparous (> 1-4) }\end{array}$ & $\begin{array}{l}3 \\
3 \\
\end{array}$ & $\begin{array}{l}50 \\
50 \\
\end{array}$ \\
\hline $\begin{array}{l}\text { Education } \\
\text { Elementary school } \\
\text { Junior high school } \\
\text { Senior high school } \\
\text { Bachelor }\end{array}$ & $\begin{array}{l}1 \\
2 \\
1 \\
1\end{array}$ & $\begin{array}{l}17 \\
50 \\
17 \\
17\end{array}$ \\
\hline $\begin{array}{l}\text { Level anxiety } \\
\text { No worries } \\
\text { Mild anxiety }\end{array}$ & $\begin{array}{l}1 \\
5\end{array}$ & $\begin{array}{l}17 \\
83\end{array}$ \\
\hline
\end{tabular}




\section{RESULT AND DISCUSSION}

Based on the results of the research that has been done, several factors that influence the level of anxiety of mothers with LBW babies are obtained as follows:

\section{Maternal Age at Pregnancy}

The results showed that there was no relationship between maternal age at pregnancy and the incidence of LBW. This is by previous research conducted byHailu and Kebede, (2018) Hailu and Kebede, (2018) which states that there is no relationship between maternal age and LBW level with a significance value of $0.256>0.05 .{ }^{9}$ Based on the results of the interview, it is known that the majority of mothers who have babies in the LBW category experience pregnancy at the ideal age (20-35 years), as many as 5 respondents or $83 \%$. These results indicate that all babies born weighing less than 2500 grams, which are dominated by the LBW category from mothers with ideal age and mothers at risk age (35 years, they cause labor with LBW because that age range the mother will have the potential to experience various kinds of complications during pregnancy and childbirth. When the mother is 35 years, mothers tend to experience pregnancy complications and fetal disorders easily. This is caused by the condition of the reproductive organs that are too old, the birth canal becomes stiff and there is a lot of decline in the function of the reproductive organs. ${ }^{10}$ Besides, there are also other contributing factors that affect the level of LBW, namely the level of education and number of family members, the frequency of maternal antenatal care (ANC) during pregnancy, and the amount of parity. ${ }^{10}$

\section{Total Parity}

Based on the research results, it is known that there is no relationship between the amount of parity and the incidence of LBW. In general, the incidence of LBW is related to premature pregnancy as well as due to dysmaturity, which means that the baby is born at term (38 weeks of gestation), but with a lower postnatal weight than during pregnancy. ${ }^{11,12}$ Low birth weight babies can be divided into Low birth weight babies (LBW) with a birth weight of 1500-2500 grams; Very Low Birth Weight (LBW) with birth weight 0.05. Parity is the number/history of maternal birth before pregnancy at this time. According to theory, the incidence of LBW will increase when the number of parity increases. When viewed from the side of maternal mortality, parity numbers 2-4 are the safest, whereas parity 1 and $>4$ are the numbers of parity at risk. Mothers with high parity, which is more than 4 , have a high risk of increasing the incidence of maternal and fetal death. This occurs because the risk of complications that are likely to be experienced will be greater and the birth distance is relatively close. In addition, when the mother has a history of high parity, the uterine muscle strength weakens and there is damage to the walls of the blood vessels in the uterus so that the nutrients that are passed on to the fetus will be inhibited. ${ }^{13}$ However, this result does not agree with Manuaba's theory from the point of view of parity which consists of one parity is unsafe, 2-3 parity is safe for pregnancy and childbirth, and parity more than 3 is not safe. This is because babies with low birth weight often occur at parity above five. After all, in these conditions, there has been a deterioration in the function of the endometrium and uterine body. High parity will cause various health problems, both for the mother and the baby who is born. One of the health impacts that are at risk of occurring at high parity is associated with the incidence of LBW.

\section{Knowledge of mothers}

Based on the results of the study, it is known that the majority of mothers who have babies with LBW conditions are at a low level of education (have graduated from junior high school and below), as many as 4 respondents. This is supported by the results of interviews which show that on average mothers have limited knowledge regarding the characteristics of LBW which then raises anxiety about the care their babies will receive. As with the results of research by Novitasari, et al., (2020) that the higher the mother's education, the better the mother's ability to make decisions regarding health services during pregnancy so that it can prevent disturbances as early as possible for the mother and her fetus. Education is also closely related to the level of knowledge of mothers about maternity care and nutrition during pregnancy. ${ }^{14}$ Besides, supervision and monitoring can also be carried out, then making efforts to prevent hypothermia in infants and help achieve normal growth. Where LBW can have a long impact on children's growth and development in the future. LBW babies have difficulty breathing, sucking, fighting infection, and keeping their body warm so that LBW babies often experience hypothermia, respiratory distress syndrome, hypoglycemia, intracranial bleeding, infection, and hyperbilirubinemia. ${ }^{8}$ Other effects of low birth weight babies include slow growth, a tendency to have a lower intellectual appearance than babies with normal birth weight. In addition, LBW babies can experience mental and physical disorders at the next developmental age so that it requires high maintenance costs. ${ }^{5}$ Husband and Family Support Based on the results of the interview, it can be concluded that the support of the husband and family has an important role for mothers who have babies with LBW conditions. The support referred to in this case can be in the form of attention, motivation, love, and assistance that can be given to mothers to take care of their babies because 2 out of 6 mothers who became respondents gave birth to twins in LBW conditions. This is by the results of research conducted byHumaira and Rifdi, (2019) Humaira and Rifdi (2019), which states that the care needed for LBW babies needs the support of the husband because with the assistance, namely the husband, the mother will feel stronger and all the things that are felt by the mother can be shared with the husband without the need to be buried alone. The Anxiety of mothers who have LBW babies Based on the results of the study, 5 out of 6 mothers who had LBW babies experienced mild anxiety about their baby's condition because they weighted normal conditions. Due to this condition, babies are more susceptible to health problems such as infections or degenerative diseases later in life. The abnormal condition of the baby after birth also requires the baby to receive intensive care at the NICU. This then makes parents often feel anxious about the development of their baby is undergoing treatment at the hospital. The results of this study are in accordance with previous studies which stated that $50 \%$ of mothers who had LBW babies who were treated in the perinatology room experienced moderate anxiety levels, $31.2 \%$ experienced severe anxiety and $18.8 \%$ experienced mild anxiety ${ }^{15}$ The inability of parents to protect babies from pain, the use of various equipment in intensive rooms, and the baby's critical condition give parents a burden on their own thoughts which in turn can cause stress. It is at this time that health education becomes important for health workers to provide to mothers which contains information 
about baby care, maternal self-care, home safety, and security and immunization. Providing education to mothers and families can increase the self-efficacy of mothers in caring for low birth weight, the results of education can reduce anxiety and increase the self-efficacy of mothers in caring for low birth weight. ${ }^{15}$. LBW conditions that experience immaturity of organ systems and respiratory disorders can be the main cause of child death. ${ }^{16}$ If the baby's condition is stable LBW, then home care can be done. The criteria for stability, in this case,

\section{CONCLUSION}

Based on the results of research in Southwest Sumba Regency regarding the factors that influence the anxiety of mothers who have LBW babies, it can be concluded that there is no relationship between the mother's age at experiencing pregnancy and the incidence rate of LBW. This is because both at ideal age and at-risk have the same opportunity to give birth to a baby with a weight under normal conditions. The amount of parity also does not affect on the incidence of $\mathrm{LBW}$ as can be observed from the same number of primiparous and multiparous mothers, namely 3 people for each category. Most mothers who have babies with LBW conditions are at a low level of education where education is related to the level of knowledge of mothers about pregnancy care and LBW babies while at home. This will then encourage the mother to experience anxiety about baby care, especially when she is in a critical condition. This is what makes the support of husbands and families have an important role for mothers with LBW babies because they can strengthen the mother's mentality and ease the workload in caring for babies. In addition, health workers have an important role in providing education and skills to increase the knowledge and ability of mothers to care for babies at home so that they can reduce the level of mother's anxiety.

\section{REFERENCES}

1. Ika. Jumlah Bayi Berat Lahir Rendah Masih Tinggi. 2015; www.ugm.ac.id. Retrieved from www.ugm.ac.id: https://www.ugm. ac.id/id/berita/10695-jumlah-bayiberatlahir-rendah-masih-tinggi

2. Humaira B, Rifdi F. Analisis Kecemasan Ibu dengan Perawatan Bayi BBLR di Rumah Sakit dr Ahmad Muchtar Bukittinggi Tahun 2018 Bunga. 2019; 1(2): 7684.

3. Gogoi N. Socio-Demographic Determinants Of Low Birth Weight In Northeastern City, India. Int J Integr Med Sci. 2018; 5(3): 587-91.

4. Putra G, Sohibien D, Yuhan Rj. Determinan Kejadian Berat Badan Lahir Rendah (BBLR) di Indonesia. J Apl Statiska Komputasi. 2019; V (11).

5. Dhilon Da, Fitri E. Pengaruh Perawatan Metode Kangguru Terhadap Kenaikan Berat Badan Pada Bayi Berat Badan Lahir Rendah (BBLR) di RS Sekabupaten Kampar Tahun 2018. J Doppler. 2019; 3(1): 1-11.

6. Hartiningrum I, Fitriyah N. Bayi Berat Lahir Rendah (BBLR) di Provinsi Jawa Timur Tahun 2012-2016. J Biometrika Dan Kependud. 2018; 7(2): 97-104.

7. Aryastami Nk, Shankar A, Kusumawardani N, Besral B, Jahari Ab. Low Birth Weight Was The Most Dominant Predictor Associated With Stunting Among Children Aged 12 - 23 Months In Indonesia. Bmc Nutr. 2017; 16. including that the baby can suck well, does not experience respiratory problems, and does not have any danger signs to the baby. Therefore, health workers have an important role in providing education and skills to increase the knowledge and ability of mothers to care for babies at home. This education is expected to increase the positive side of the mother and the family so that it can reduce anxiety while caring for the baby and still be able to meet the baby's needs to avoid unwanted things.

8. Mutiara S, Hastuti Rp. Faktor-Faktor yang Berhubungan dengan Tingkat Kecemasan Orang Tua Bayi BBLR di RSUD HM Ryacudu dan RS Handayani Kotabumi Lampung Utara Pendahuluan. Vol. 9, Jurnal Kesehatan Metro Sai Wawai. 2016. P. 51- 5.

9. Hailu Ld, Kebede Dl. Determinants Of Low Birth Weight Among Deliveries At A Referral Hospital In Northern Ethiopia. Biomed Res Int. 2018; 1-9.

10. Perwiraningtyas P, Ariani Nl, Anggraini Cy, Ilmu F, Universitas K, Tunggadewi T. Analisis Faktor Resiko Tingkat Berat Bayi Lahir Rendah. 2018; 3(3).

11. Kusparlina Ep. Hubungan Antara Umur dan Status Gizi Ibu Berdasarkan Ukuran Lingkar Lengan atas dengan Jenis BBLR. 2016; VII(1): 21-6.

12. Sembiring Jb, Pratiwi D, Sarumaha A. Hubungan Usia, Paritas dan Usia Kehamilan dengan Bayi Berat Lahir Rendah di RSU Mitra Medika Medan Periode 2017. J Bidan Komunitas. 2017; I(1): 38-46.

13. Khoiriah A. Hubungan Antara Usia dan Paritas Ibu Bersalin Dengan Bayi Berat Lahir Rendah (BBLR) di Rumah Sakit Islam Siti Khadijah Palembang. Jurnal Kesehatan. 2015; VIII(2): 310-4.

14. Novitasari A, Hutami Ms, Pristya Tyr. Pencegahan dan Pengendalian BBLR di Indonesia: 2020; 2(3): 175-82.

15. Indrayati N, Santoso Dya. Kesiapan Orangtua dalam Merawat Bayi Berat Lahir Rendah Melalui Edukasi Perawatan BBLR. 2020; 3(4): 549-56.

16. Cutland $\mathrm{Cl}$, Lackritz Em, Mallett-Moore T, Bardají A, Chandrasekaran R, Lahariya C, Et Al. Low Birth Weight: Case Definition \& Guidelines for Data Collection, Analysis , And Presentation Of Maternal Immunization Safety Data. Vaccine. 2017; 35(48): 6492-500. Available Https://Doi.Org/10.1016/J.Vaccine.2017.01.049 